\title{
Article
}

http://dx.doi.org/10.11646/phytotaxa.227.2.1

\section{Achnanthes citronella, A. trachyderma comb. nov. (Bacillariophyta) and allied taxa pertaining to the same morphological group}

\author{
CATHERINE RIAUX-GOBIN ${ }^{1,2,}{ }^{*}$, PIERRE COMPÈRE ${ }^{3}$, FRIEDEL HINZ ${ }^{4} \&$ LUC ECTOR $^{5}$ \\ ${ }^{1}$ CRIOBE-USR 3278 CNRS-EPHE-UPVD \\ ${ }^{2}$ Laboratoire d'Excellence 'CORAIL', F-66000 Perpignan, France \\ ${ }^{3}$ Botanic Garden Meise, B-1860 Meise, Belgium \\ ${ }^{4}$ Hustedt Diatom Study Centre, Alfred Wegener Institut für Polar- und Meeresforschung in der Helmholtz Gemeinschaft, D-27570 \\ Bremerhaven, Germany \\ ${ }^{5}$ Environmental Research and Innovation Department (ERIN), Luxembourg Institute of Science and Technology (LIST), L-4422 Belvaux, \\ Luxembourg \\ *Corresponding author (E-mail: catherine.gobin@univ-perp.fr)
}

\begin{abstract}
Several diatoms in the family Achnanthaceae (Bacillariophyta), mainly from marine environments, have species with strongly apiculate, lemon-shaped valves. Some of them originally described under the genus Cocconeis (i.e., C. trachyderma or C. citronella), while others were first described as Stauroneis species [i.e. Stauroneis apiculata or S.(?) obesa]. Afterwards, Cocconeis citronella has been recombined within Achnanthes by Hustedt. The type material of C. citronella from Albert Mann's collection, housed in the Smithsonian Institution (US), has been examined with light microscope; some ambiguities are pointed out and new details added to the original description. The intricate history of the latter taxon is redrawn and comparison with allied taxa are tentatively addressed. Cocconeis trachyderma is lectotypified and recombined as Achnanthes trachyderma comb. nov. Stauroneis apiculata and S.(?) obesa are recombined as Achnanthes apiculata comb. nov. and Achnanthes obesa comb. nov. respectively. The examination with light and scanning electron microscope of several marine samples from the Society Archipelago details the unique morphology of Achnanthes trachyderma which, until recently, has been often misidentified as Achnanthes citronella due to certain similarities between both taxa.
\end{abstract}

Key words: Achnanthes citronella, A. trachyderma comb. nov., Achnanthales, morphology, Indo-Pacific Basin, SEM

\section{Introduction}

Some benthic marine diatoms species in the order Achnanthales (Bacillariophyta) present valves of a characteristic apiculate or lemon shape (Figs 1-24). Several of them were first described as species of Cocconeis [i.e. Cocconeis citronella A.Mann (1925: pl. 13, figs 3-6, reproduced here as Figs 15-17), C. trachyderma F.Meister (1935: figs 63, 64, reproduced here as Figs 19, 20)] while some others, bearing some similarity with the latter, were first described amongst the biraphids, such as Stauroneis(?) obesa Greville (1866: pl. 3, fig. 12, here reproduced as Fig. 4) or Stauroneis apiculata Greville (1859: pl. 4, fig. 8, here reproduced as Fig. 1), when they are actually monoraphid diatoms. Some of these taxa, probably pertaining to the same morphological group, have been later transferred to Achnanthes, several of them having an intricate taxonomic history resulting in some taxonomic confusions.

Some papers illustrate diatoms identified as Achnanthes citronella (A.Mann) Hustedt in Schmidt et al. (1937: pl. 415, figs 3-8) with light (LM), scanning electron (SEM) and transmission electron (TEM) microscope, e.g. Meister (1935: 98, pl. 6, fig. 53), Foged (1975: 7, pl. 9, fig. 13), Gerloff \& Helmcke (1977: pls 939-945), Foged (1984: 12, pl. 32, fig. 10); Podzorski \& Håkansson (1987: 41, pl. 12, fig. 1), Navarro et al. (2000: pl. 14, figs 5-7), Riaux-Gobin et al. (2011: 13, pl. 1, fig. 6; pl. 8, figs 1-3), Lobban et al. (2012: 285, pl. 38, figs 5, 6), Stidolph et al. (2012: pl. 21, fig. 12) and Wisshak et al. (2014: 115, fig. 3F). All the latter works refer to taxa with diverse morphologies, sometimes without illustrating both valves (sternum valve, SV and raphe valve, RV).

On the other hand, Montgomery (1978: pl. 72, figs C-G, SEM) illustrated diatom specimens as Cocconeis trachyderma F.Meister (1935: 99, figs 63, 64) with features very close to those of Achnanthes citronella. 

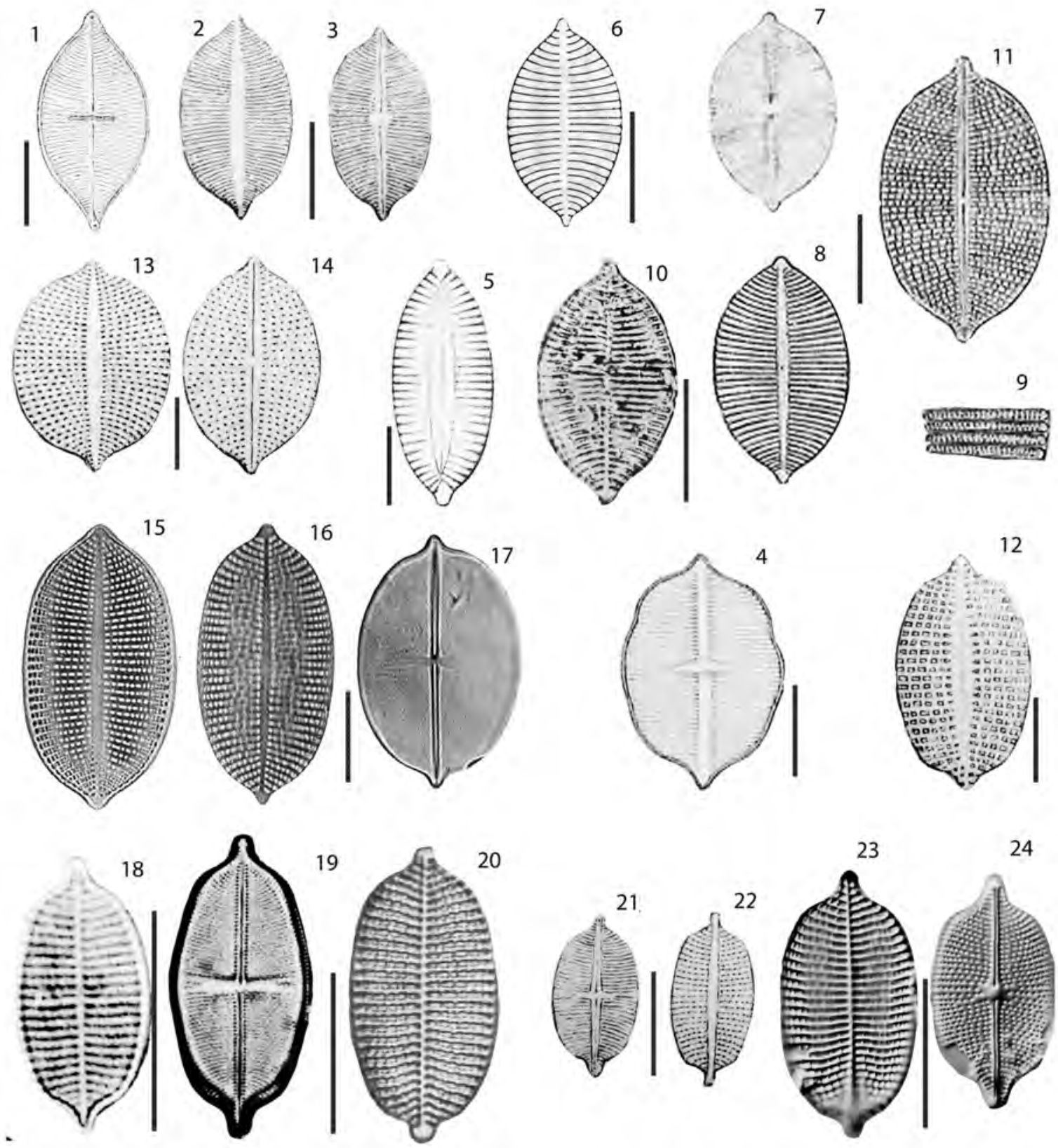

FIGURES 1-24. 1. Stauroneis apiculata. 2, 3. Cocconeis apiculata. 4. Stauroneis(?) obesa. 5. Cocconeis robusta. 6. Rhaphoneis mammalis. 7-9. Achnanthes mammalis. 10. Achnanthes mammalis var. reticulata according to Foged (see text, reproduced with permission of E. Schweizerbart). 11. Achnanthes (Actinoneis) mammalis var. reticulata. 12. Unnamed individual in Schmidt et al. (1895, pl. 198, fig. 40). 13, 14. Cocconeis citrina. 15-17. Cocconeis citronella. 18. Cocconeis sabangi. 19, 20. Cocconeis trachyderma. 21, 22. Achnanthes schmidtii. 23, 24 Achnanthes schmidtii (reproduced with permission of E. Schweizerbart). Scale bars $=20 \mu \mathrm{m}$.

The above remarks point that several taxa from the Achnanthes citronella group are difficult to discriminate and define clearly. We here i) clarify the nomenclatural history of Achnanthes citronella, ii) propose a new synonym to the latter, iii) detail the SEM morphology of the close taxon first described as Cocconeis trachyderma, iv) propose several new combinations concerning some allied taxa, and v) propose a tentative identification key mainly based on LM examinations. 


\section{Materials and Methods}

Materials used in this study are derived from several sources (Table 1):

TABLE 1. Type slides examined. Slides cited or labelled by the author to contain this species. * in Riaux-Gobin et al. (2014). US = Smithsonian Institute. Z = Zurich University Herbarium. BR = Natural History Museum. - = no data.

\begin{tabular}{|c|c|c|c|c|c|c|}
\hline Species & Type & Slide & Collection & Housed & Guide $\mathbf{n}^{\circ}$ & Fig. \\
\hline Cocconeis citronella & + & Cat. \# 43609 & A. Mann & US & D2312 & 44 \\
\hline Cocconeis citronella & - & 2202 & A. Mann & US & D2314 & 52 \\
\hline Cocconeis citronella & - & 3905 & A. Mann & US & D4518 & 54 \\
\hline Cocconeis citronella & - & 2201 & H.W. Henshaw & US & D2313 & 53 \\
\hline Cocconeis trachyderma & - & Nagasaki 3409000 & F. Meister & $\mathrm{Z}$ & - & *fig. 1 \\
\hline Cocconeis trachyderma & - & Nagasaki 3409001 & F. Meister & $\mathrm{Z}$ & - & *fig. 1 \\
\hline Cocconeis trachyderma & - & Nagasaki 3409003 & F. Meister & $\mathrm{Z}$ & - & *fig. 1 \\
\hline Cocconeis trachyderma & - & Nagasaki 3409008 & F. Meister & $\mathrm{Z}$ & - & - \\
\hline Cocconeis trachyderma & - & Nagasaki 3409010 & F. Meister & $\mathrm{Z}$ & - & - \\
\hline Cocconeis trachyderma & - & Nagasaki 3409011 & F. Meister & $\mathrm{Z}$ & - & - \\
\hline Cocconeis trachyderma & - & Nagasaki 3409017 & F. Meister & $\mathrm{Z}$ & - & - \\
\hline Cocconeis trachyderma & - & Nagasaki off shells 22045 & M. Voigt & Eawag, Dübendorf & - & - \\
\hline Cocconeis trachyderma & - & Nagasaki off shells 22046 & M. Voigt & Eawag, Dübendorf & - & - \\
\hline Cocconeis trachyderma & - & Nagasaki off shells 22047 & M. Voigt & Eawag, Dübendorf & - & - \\
\hline Stauroneis apiculata & - & Patos guano & R.K. Greville & $\mathrm{BR}$ & BM 1753 & - \\
\hline Stauroneis(?) obesa & + & Curteis Straits Queensland & R.K. Greville & $\mathrm{BR}$ & BM 2736 & - \\
\hline Stauroneis obesa & - & - & R.K. Greville & $\mathrm{BR}$ & BM 2593 & - \\
\hline ?Achnanthes mammalis & - & - & R.K. Greville & $\mathrm{BR}$ & BM 2887 & - \\
\hline
\end{tabular}

a) Albert Mann's slide collection: Type slide Cat. \# 43609. Labelled 'C. citronella A.Mann'. Holotype: From Philippines (Jolo Jolo, Sulu Island) 3-17. Slide 2202, from Philippine Islands, labelled 'C. citronella Mann nom. nov'. Slide 3905, Mann Phil. Diat., from Laysan Island \#1 4/11/23, labelled ‘C. citronella Mann'. These slides are housed in the Smithsonian Institute, Washington (US).

b) Henry Wetherbee Henshaw's collection: slide 2201 from Jolo, Sulu Island 3-4-17. Labelled 'C. citronella Mann nom. nov.'. This slide is housed in US.

c) Friedrich Meister's type material: F. Meister's slides are housed in the Zurich University Herbarium (Z). The slides 'Nagasaki 3409000'- '01', '03'- '08', '10'- '11'- '17' have been examined. F. Meister's handwritten notes assign these slides to the shell of a marine snail from Nagasaki (Japan), material collected by M. Voigt (Meister 1935: 96). These slides are supposed to contain Cocconeis trachyderma. Some Meister's notes roughly indicate the position of remarkable taxa on the slides, but no indication concerns Cocconeis trachyderma.

d) Manfred Voigt's slide collection: Several M. Voigt's slides have been prepared from the same sample than those from F. Meister (see above, 'Nagasaki off shells', 22045-46-47). The slide 22045 was pointed out, in M. Voigt's hand notes, to contain Cocconeis trachyderma. These slides are housed in the Swiss Federal Institute of Aquatic Science and Technology, Dübendorf.

e) Robert Kaye Greville’s slide collection: Patos guano, BM 1753 containing Stauroneis apiculata Greville (1859: 30). Curteis Straits Queensland, coll. Dr. Roberts, BM 2736, holotype of Stauroneis(?) obesa Greville (1866: 237). Also from R.K. Greville's slide collection: BM 2593 and BM 2887. These slides are housed in the Natural History Museum, London (BM).

f) Society Archipelago material and preparation: The marine benthic samples were collected in Tahiti and Moorea Islands (from intertidal surface sediment, coral debris and lagoon macroalgae) and preserved in formaldehyde (10\% 
final concentration). For SEM examination, the samples were filtered through $1 \mu \mathrm{m}$ Nuclepore filters and rinsed twice with deionised (milliQ) water to remove salts. Filters were air-dried and mounted onto aluminum stubs before coating with gold-palladium alloy (EMSCOP SC 500 sputter coater) and examined with a Hitachi S-4500 SEM operated at $5 \mathrm{kV}$ (C2M, Perpignan University, France). For LM examination, the sample was washed with distilled water to remove salts, treated with $30 \% \mathrm{H}_{2} \mathrm{O}_{2}$ for $2 \mathrm{~h}$ at $70{ }^{\circ} \mathrm{C}$ to remove organic matter, rinsed several times in distilled water, alcohol-desiccated and mounted on glass slides using Naphrax $^{\circledR}$ (Oscar E. Romero, pers. com.). Diatom slides were examined with a Zeiss Axiophot 200, with differential interference contrast (DIC) optics and photographed with a Canon PowerShot G6 digital camera (CRIOBE, France).

For the description of the frustule, terminology follows Anonymous (1975), Ross et al. (1979) and Round et al. (1990). As previously proposed, in particular by Riaux-Gobin et al. (2013), we designate the valve with a raphe as the raphe valve (RV) and the valve without a raphe as the sternum valve (SV).

\section{Results}

Achnanthes citronella has been more or less recently illustrated with different morphologies (see above). The examination of the type slide 43609 (D 2312 in US) allowed us to amend the original description and raise some ambiguities. Several taxa similar to Achnanthes citronella are detailed in Table 2, briefly described below or more extensively described and illustrated (i.e., Cocconeis trachyderma). Along their somewhat taxonomic intricate history, several of these allied taxa were previously proposed as synonyms. A tentative morphological identification key is proposed.

Achnanthes citronella (A.Mann) Hustedt in Schmidt et al. (1937: pl. 415, figs 3-8) (Table 2) emend. Riaux-Gobin (Figs 15-17, 25, 26, 33, 35-38).

Basionym: Cocconeis citronella A.Mann (1925: pl. 13, figs 3-6, reproduced here as Figs 15-17).

Heterotypic synonym: Achnanthes mammalis var. reticulata Cleve (1895: 187), syn. nov. As stated by Mann (1925: ‘Cleve’s form’ [actually a variety] seems to be the same as [...] in Schmidt's Atlas: plate 198, figs 35, 36, 40' (fig. 40 reproduced here as Fig. 12). Achnanthes mammalis var. reticulata (Fig. 11) is proposed to be a synonym of Achnanthes citronella since the morphology of the SV by Cleve fits that by A. Mann (Fig. 15), and because Achnanthes mammalis var. reticulata lacks the double striation present in Achnanthes mammalis sensu Cleve (Figs 8, 9, see description below).

Original diagnosis:- 'Valves broadly oval with apiculate apices; lower valve with delicate radiating beaded lines closely set, slightly more evident in a band near each margin, otherwise very obscure and misty; almost reaching the raphe but lacking on either side of the central nodule, so that a hyaline stauros is produced which is about one-fifth the width of the valve; upper valve with widely set rows of coarse rectangular beads radially arranged and slightly curved toward the two apices, the outer beads of these rows next to the margins of the valve being plainly larger than the others; a hyaline median line corresponding to the raphe line of the lower valve. Length of valve $0.062-0.070$; width of valve $0.034-0.039$; lines on upper valve 6.5 in $0.01 \mathrm{~mm}$.; lines on lower valve $21-25$ in $0.01 \mathrm{~mm}$ (Mann 1925: 61).

Type:-PHILIPPINE ISLANDS. Sulu: Jolo Jolo (holotype: slide 43609, US! D 3212, here illustrated as Fig. 34, see Table 1).

Type observation and amended description:-The shape of the valves (Figs 25, 26) is broad-elliptical with apiculate apices (lemon-shaped), with no clearly-marked shoulders near the apices. The SV striae are composed of quadrangular areolae (with no axial arrangement, Figs 25, 33), radiate on all valve long and marginally curved at the apices (Fig. 38). The SV apices lack areolae (Fig. 38). The SV sternum is slightly elliptical and larger on the centre of the valve (Fig. 25, arrowhead). The SV stria density is 6.5-7.5 in $10 \mu \mathrm{m}$. The two published RV valves (figs 5, 6, op. cit.) are the same one oriented in opposite ways: they correspond to the RV mounted on the type slide. The RV valcocopula (RVVC) is open and lacks fimbriae (Fig. 26, arrow). The RV (Figs 35-37) stria density is 13.5-17.0 in $10 \mu \mathrm{m}$ in midhemivalve, 17.5-18.0 along the raphe, 21-24 on the extreme margin (Fig. 36, arrowhead), vs. 21-25 in the original diagnosis. The central area is enlarged in a butterfly-shaped stauros (Fig. 35), relatively high and reaching not more than half-hemivalve (Fig. 35, arrowheads).

Remarks and ambiguities:- - Hustedt in Schmidt et al. (1937: pl. 415, figs 3-8) established the combination Achnanthes citronella (A.Mann) Hustedt with Cocconeis citronella A.Mann (1925: 61) as basionym, Cocconeis sabangi F.Meister (1932: 12) as a probable synonym and rejecting Achnanthes mammalis (Castracane 1886: 48) Cleve (1895: 187) as synonym, 'since Castracane showed only one valve that could belong to different species'. 


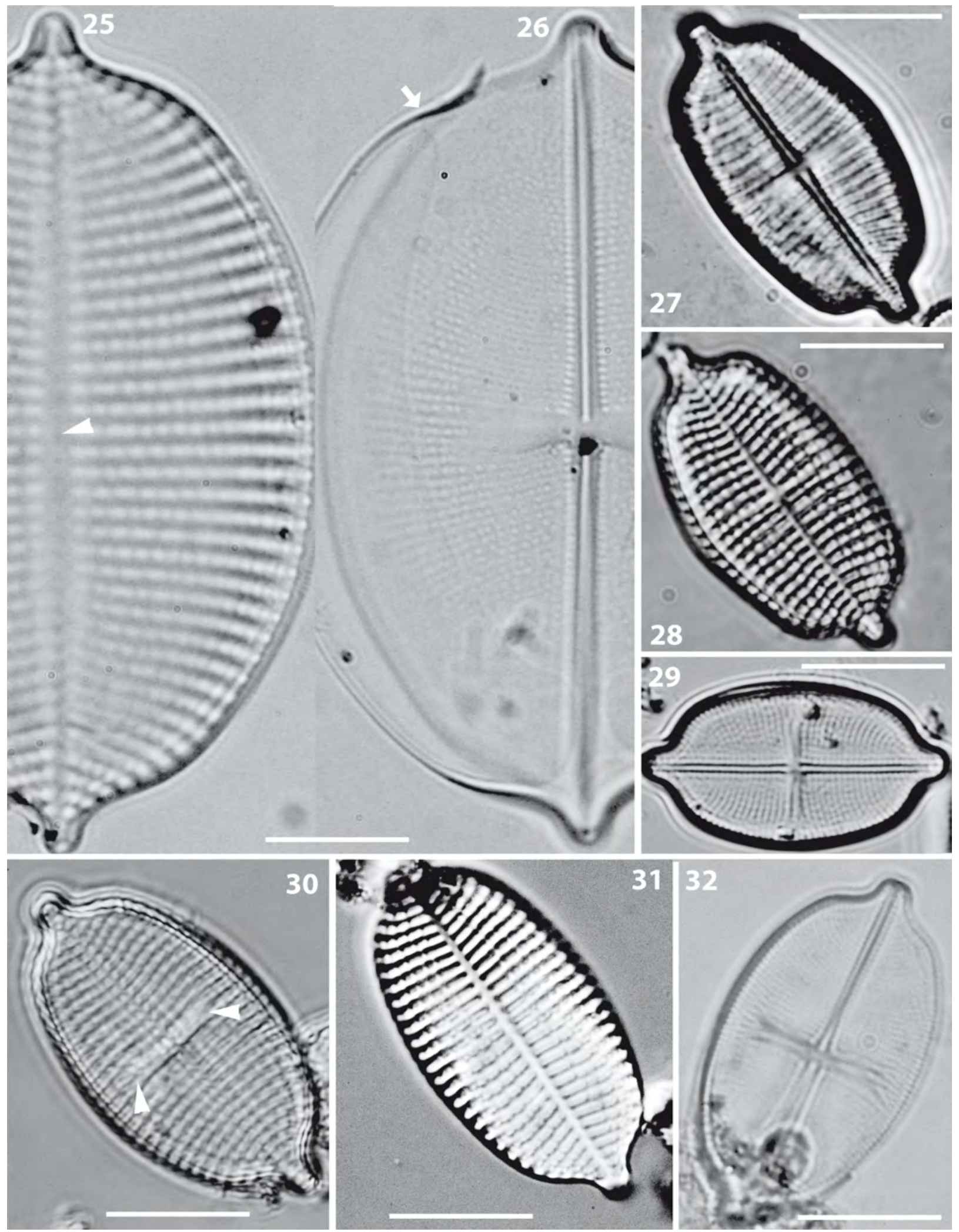

FIGURES 25-32. 25, 26. Achnanthes citronella. Individuals from type slide 43609, labelled as 'Jolo Jolo, Sulu, Philippine Islands, 3-17' (see Fig. 34), A. Mann's collection, housed in US. Lemon-shaped SV with an elliptic SV sternum (Fig. 25, arrowhead) and rectangular areolae without axial arrangement, RV finely striated, detached open valvocopula without fimbriae (Fig. 26, arrow) and a short butterflyshaped stauros. 27-32. Achnanthes trachyderma. 27-29. Individuals from Meister's slides collection, housed in Z. Frustule from slide 3409001 showing a large RV stauros and fine RV striae (Fig. 27), and SV coarse striation (Fig. 28). 29. Illustration of the lectotype. A RV from slide 309008, with a fine striation and a narrow extended stauros. 30-32. Achnanthes trachyderma. Individuals from Society Archipelago, South Pacific, with relatively large stauros (Fig. 30, arrowheads), SV striae parallel, only slightly radiate at the apices, narrow sternum (Fig. 31). 32. RV with fine striae and large and thin stauros. Scale bars $=10 \mu \mathrm{m}$. 


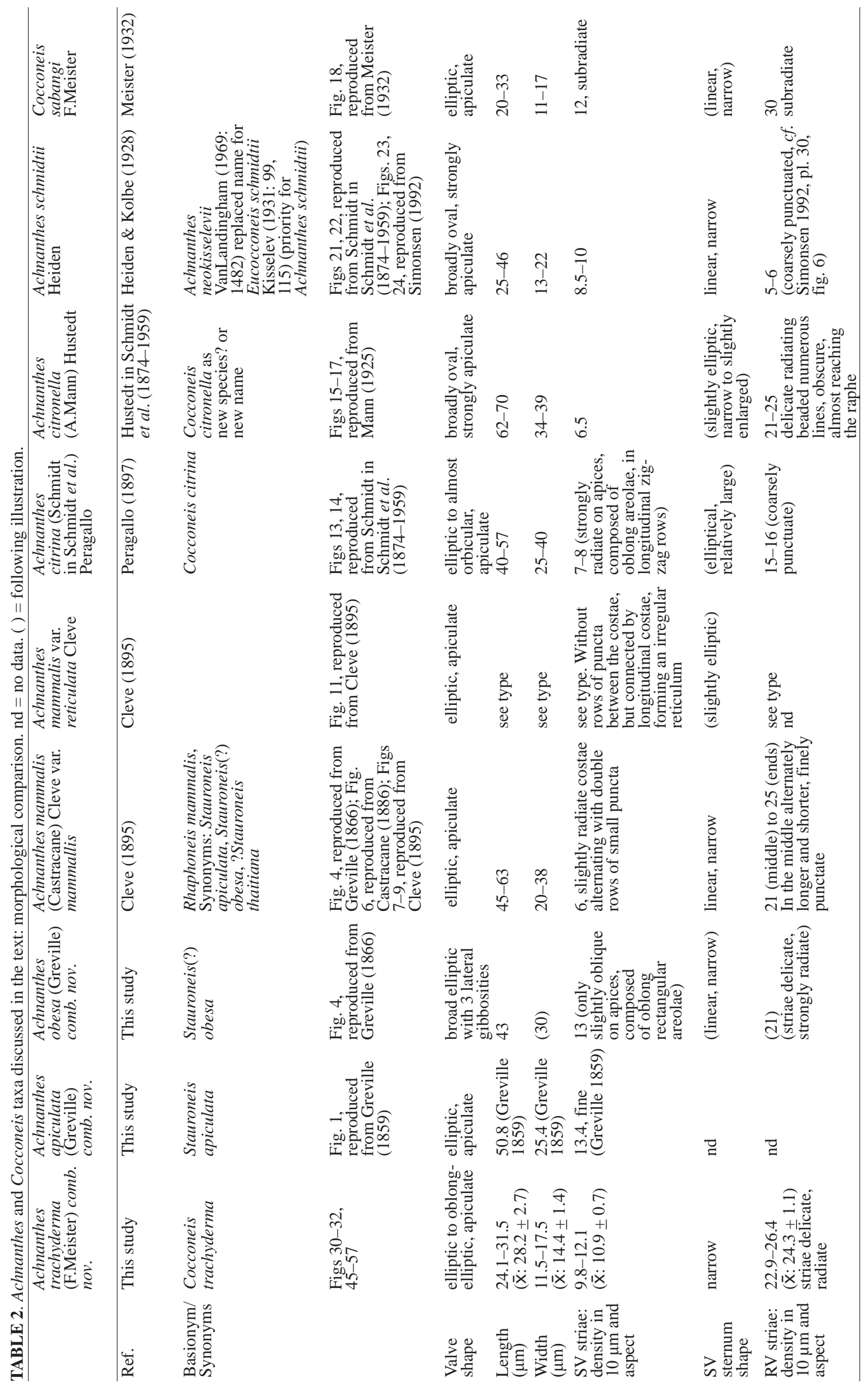



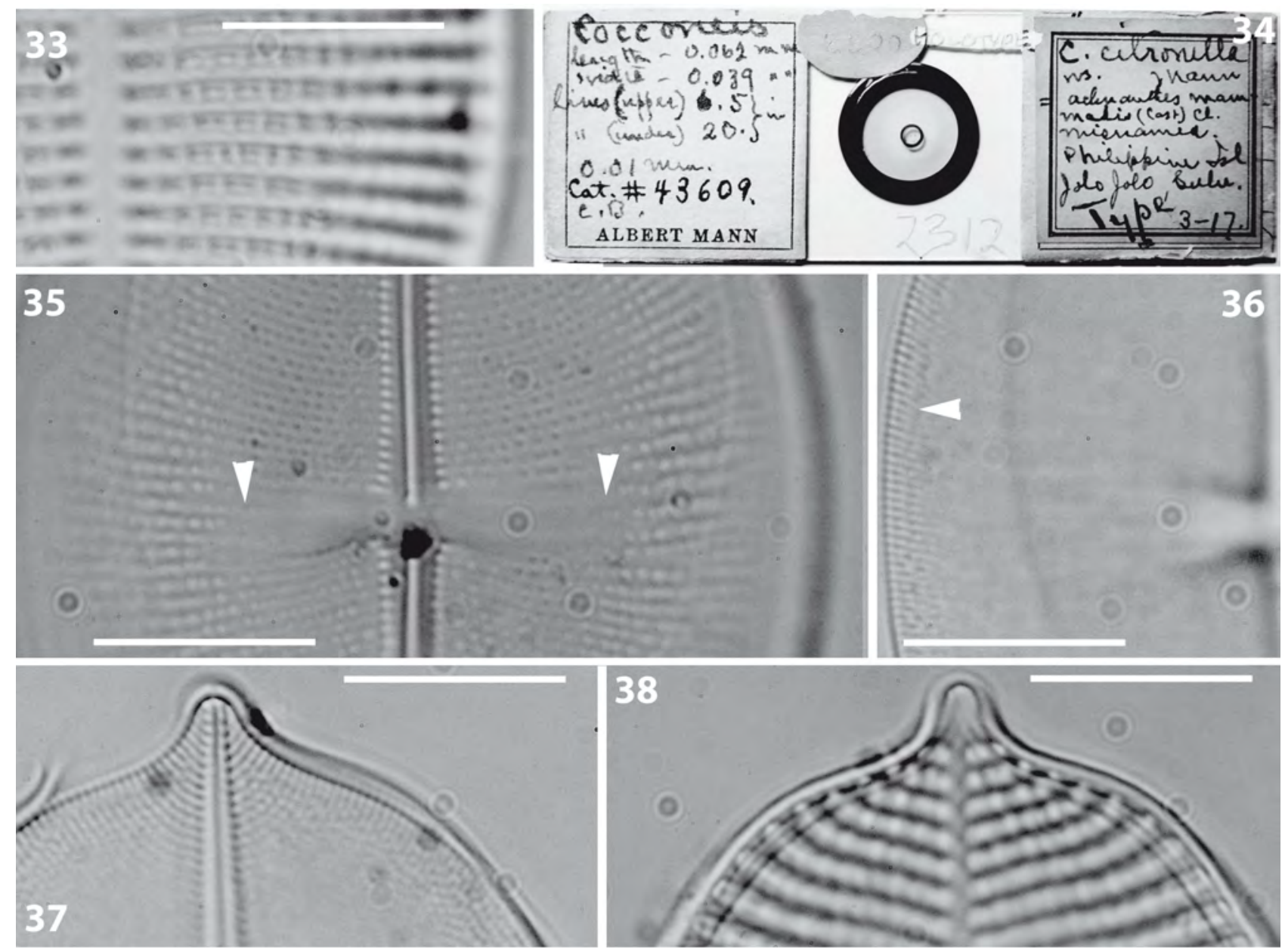

FIGURES 33-38. Achnanthes citronella. 33. Details of the SV striation. 34. Type slide 43609. 35. RV central area with the short and high/thick stauros (arrowheads). 36. Marginal dense RV striae (arrowhead). 37. RV apex with curved striae regularly spaced. 38. SV apex lacking areolae. Scale bars $=10 \mu \mathrm{m}$.

Surprisingly, Mann (1925: pl. 13, figs 3-4) did not illustrate the SV selected by himself as type material (see Fig. 25), but two other SVs that are narrower (elongate to linear-elliptical), with a larger sternum and a low stria density (Figs 15, 16). It would have been interesting to search for more valves in the original raw material (Jolo Jolo, Philippines), but neither the slides made from the raw type material, nor other mounted $C$. citronella RVs are available from A. Mann's collection. On the other hand, three slides labelled as 'C. citronella Mann nom. nov.', housed in US, only contain each one isolated SV valve of the species: 1) Fig. 39, from slide 2202 (Fig. 42), upper valve, from Philippine Islands, Albert Mann collection, annotated: ‘0.070x0.034 mm, Sch. At. 198, 40, no name?’, 2) Fig. 40, from slide 2201 (Fig. 43), from Jolo, Sulu Td. 3-4-17, H.W. Henshaw collection, annotated: '0.070x0.037 mm upper valve' and 3) Fig. 41, from slide 3905 (Fig. 44), Laysaw Is. \#1, wash from algae in $3 \mathrm{ft}$. of water onshore reef. 4/11/23, Albert Mann collection, annotated: 'length 0.033 1/2 normal size, Mann Phil. Diat. Styrax 6/24'. The individuals illustrated in Figs 39, 40 have a large size, a large SV sternum and a low SV stria density $(<6$ in $10 \mu \mathrm{m})$, while the individual illustrated in Fig. 41 has a small length, a narrow SV sternum, areolae present on apices and dense SV striae (ca. 12 in $10 \mu \mathrm{m}$ ). The latter individual (as annotated on the label) does not fit the original diagnosis of Achnanthes citronella and probably pertains to Achnanthes trachyderma (see below).

Meister (1935) showed some doubts concerning the correspondence of the RV valve of Cocconeis citronella illustrated by Mann (1925: figs 5, 6, reproduced here as Fig. 17) to the SV illustrated in figs 3, 4 (op. cit., reproduced here as Figs 15, 16). The shape of the unpublished SV from the type slide material (Fig. 25) obviously pertains to a different taxon than the one corresponding to the published SVs (Figs 15, 16). Unfortunately, Mann (1925) provides only one RV image (Figs 17, 26), so, it is difficult to insure the correspondence of this RV to the published SVs. Our hypothesis is that Figs 25, 26 possiby refer to a new and true Cocconeis (Achnanthes) citronella, while Figs 15, 16 better fit in another taxon such as that illustrated in Fig. 11 (Achnanthes mammalis var. reticulata). 
Cocconeis citronella —new species vs. new name:-In the protologue, A. Mann showed some hesitation between 'replacement name' (nom. nov.) for Achnanthes mammalis sensu P.T. Cleve non (Castracane) Cleve, and name of a new species for his Cocconeis citronella [see the original diagnosis entitled: 'Cocconeis citronella, new species?'; the annotation 'nom. nov.' on several slides and 'new name' on captions (op. cit.: 178, pl. 13, figs 3-6); and the annotation on the type slide 43609 (see Fig. 34): 'C. citronella ns Mann = Achnanthes mammalis (Cast.) Cl. misenamed']. Mann (1925: 61) obviously did not examine the type of Rhaphoneis mammalis and decided quite arbitrarily to describe his material as a new taxon. However, according to McNeill et al. (2012: art. 41.7, Note 3), Cocconeis citronella A.Mann is the name of a new species and cannot be a replacement name.

\section{Allied taxa pertaining to the Achnanthes citronella morphological group and doubtful taxa}

Achnanthes trachyderma (F.Meister) comb. nov. (Figs 19, 20, 27-29, Table 2)

Basionym: Cocconeis trachyderma F.Meister, Berichte der Schweizerischen Botanischen Gesellschaft 44: 99, figs 63, 64. 1935 (figures reproduced here as Figs 19, 20).

Translation of the original diagnosis:- 'Valves elliptical with elongate, capitate endings, 29 to $32 \mu \mathrm{m}$ long, 14 to $15 \mu \mathrm{m}$ wide. Raphe valve with 26 radiate, punctuate-dotted striae and a stauroid central area, which extends beyond the midline of the half valve. Rapheless valve with a very narrow pseudoraphe and 9 to 11 coarsely punctate striae in $10 \mu \mathrm{m}$. Not rare in Nagasaki'.

Type:-JAPAN. Nagasaki, 'shell of a marine snail from Nagasaki', see Materials \& Methods (lectotype here designated among the numerous slides from Nagasaki studied by Meister and containing this species: Z!, slide 3409008 in coll. F. Meister’s, illustrated here as Fig. 29. See Table 1).

Type observation:-The taxon is rare in F. Meister's and M. Voigt's slides. The individuals are small (ca. $25.6 \mu \mathrm{m}$ long, $13.2 \mu \mathrm{m}$ wide; $c a .11 .5 \mathrm{SV}$ striae in $10 \mu \mathrm{m}$ and $25.5 \mathrm{RV}$ striae in $10 \mu \mathrm{m}$ ), relatively narrow (L/W: 1.94$)$, with wellmarked shoulders near the apices. The RV stauros is wide-ranging and thin, reaching almost the margins (Fig. 29). It can be remarked that the Nagasaki material also contains individuals slightly bigger (ca. $33.1 \mu \mathrm{m}$ long, $17.4 \mu \mathrm{m}$ large, 10.2 SV striae in $10 \mu \mathrm{m}$ and 21.3 RV striae in $10 \mu \mathrm{m}$ ) but with an extended stauros as in the smaller individuals.

Remarks:-M. Voigt, in his hand notes about 'Cocconeis trachyderma v. elliptica Mfrd. Vgt.' (an undescribed variety marked from slide 22045, Nagasaki: 'similar Meister's type') refers to 'Achnanthes?' as a remark, proving his doubts about its belonging to Cocconeis. Meister (1935: 99) also illustrated a SV of Cocconeis citronella from his Nagasaki material, with the remark that the latter has a lanceolate pseudoraphe, being narrow in Cocconeis trachyderma. Furthermore, Meister (1935: 99) specified that the central area is much shorter in Cocconeis citronella than in C. trachyderma.

Material from Society Archipelago (South Pacific):-(LM: n=3, Figs 30-32; SEM, n=21, Figs 45-57). The individuals from the Society Archipelago are always small $(25.6+2.9 \mu \mathrm{m}$ long; $13.2 \pm 0.9 \mu \mathrm{m}$ wide), the SV stria density is higher than in A. citronella (Table 1) and the stauros is extended; the SV sternum is narrow. This taxon is frequent in Tahiti and Moorea Islands. The morphology of the South Pacific taxon (Figs 30-32) roughly matches that of Achnanthes trachyderma comb. nov. The SEM examination allows to add some details to the diagnosis: the SV is strongly convex, one row of SV large areolae lies on each side of the narrow sternum (Figs 45-47), the SV apices are void of areolae except in rare cases (Fig. 46, arrowhead), the valvocopula system lacks fimbriae (Fig. 47, arrowhead). The SV areolae hymenes are externally smooth (with no apparent perforations or slits, Fig. 49), and lying under the valve face (Fig. 49, arrow); in internal view they show a complex structure with a grid pattern (Figs 48, 50, 51). The cingulum is composed of the valvocopulae and an additional copula (C in Fig. 49). The SV striae (11.5 \pm 0.7 striae in $10 \mu \mathrm{m}$ ) are parallel in mid-valve to only slightly radiate at the apices (Fig. 50). The RV is slightly concave (Fig. 52), finely striated ( $25.5 \pm 1$ striae in $10 \mu \mathrm{m})$, with striae strongly radiate and composed of small areolae internally closed by domed hymenes (Fig. 55, arrowhead), with one row of longer areolae near the margin (Fig. 52, arrow). The raphe is filiform and straight, the axial area narrow, the central raphe endings straight and close to each other, the terminal raphe fissures very slightly undulating and continuing on the mantle (Figs 56, 57). The central area is enlarged in a narrow but extended stauros delineated on the margins by short striae (Fig. 53, arrow; Fig. 54, arrowheads). Helictoglossae are low (Fig. 53, arrowhead). 

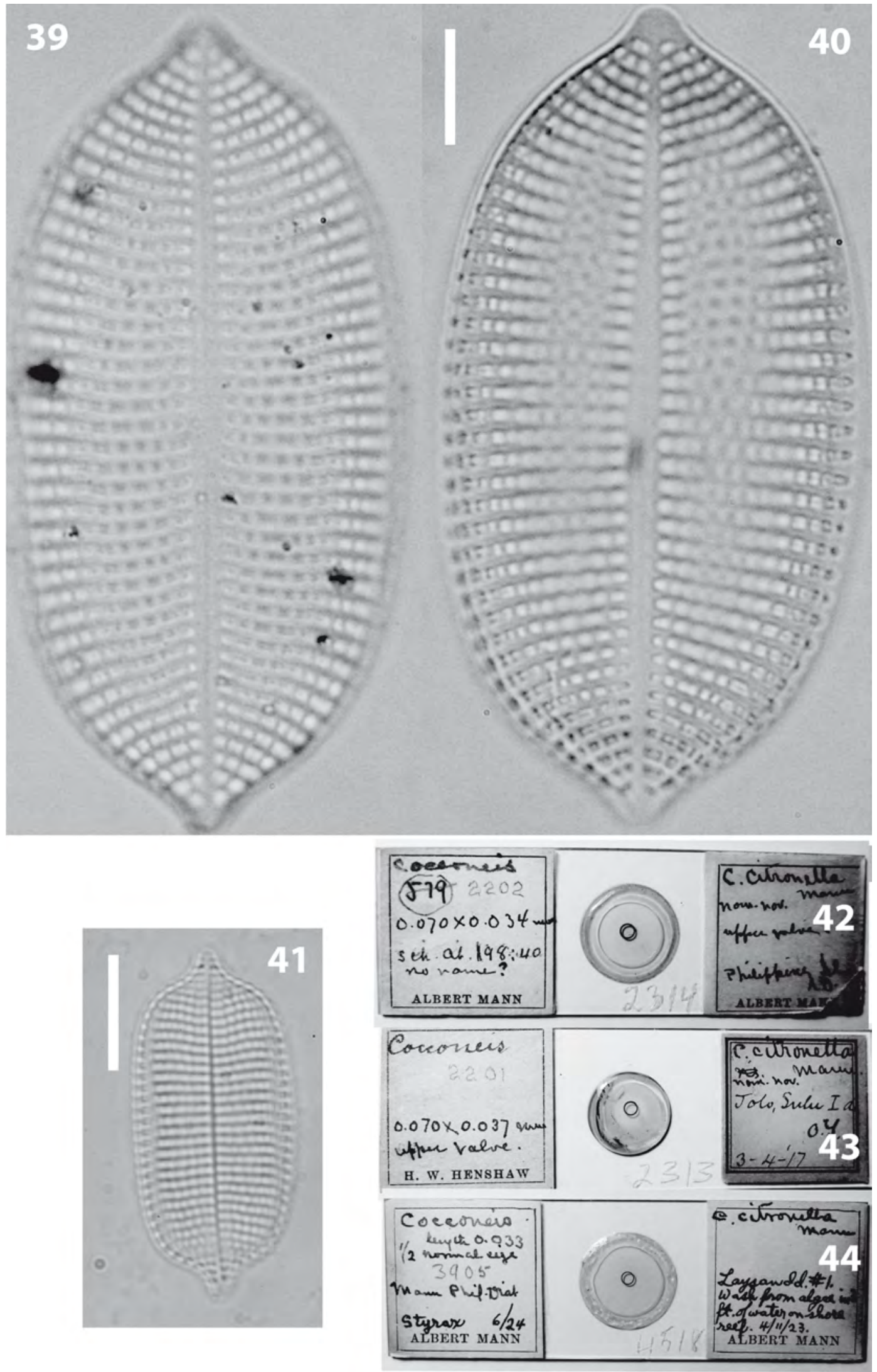

FIGURES 39-44. Achnanthes citronella. 39, 40. Large oblong-elliptic individuals with coarse SV striation. 41. Small-celled individual with dense SV striation (see text). 42. Slide 2202 from A. Mann collection labelled as ‘C. citronella Mann nom. nov.’ . 43. Slide 2201 from H.W. Henshaw collection labelled as 'C. citronella Mann nom. nov.'. 44. Slide 3905 from A. Mann collection labelled as 'C. citronella Mann 1/2 normal size’. Scale bars $=10 \mu \mathrm{m}$. 

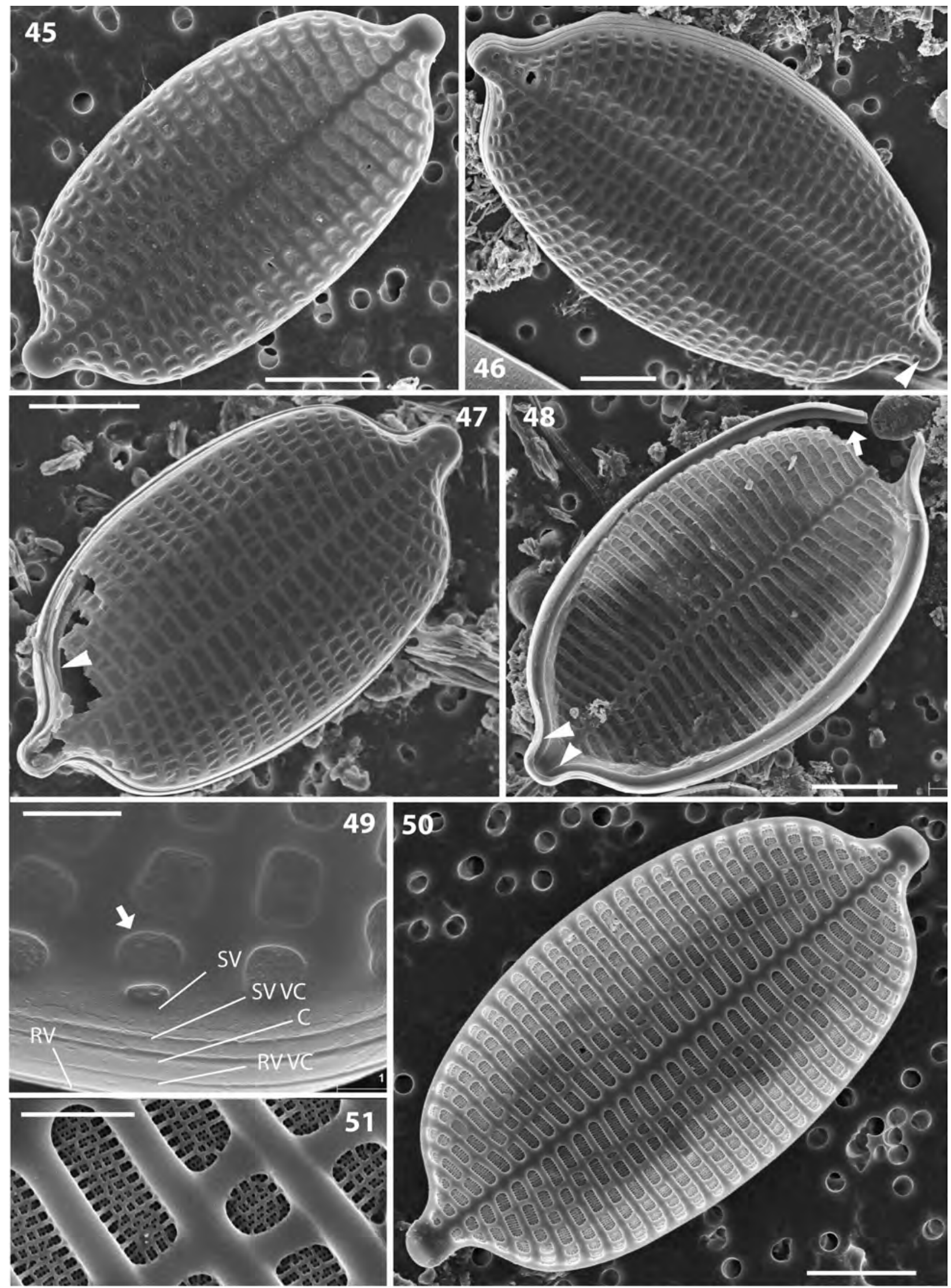

FIGURES 45-51. Achnanthes trachyderma. Individuals from Society Archipelago, SEM. 45. SV external side, with narrow sternum. 46. Apices with areolae (arrowhead). 47. Valvocopulae system lacking fimbriae (arrowhead). 48. SV internal side, with open SVVC (arrow) and no fimbriae (arrowheads). 50. Internal SV areolae pattern and no areolae on apices. 49. Detail of the cingulum composed of the two valvocopulae (SVVC and RVVC) and a supplementary copula (C). 51. Detail of the internal structure of the SV areolae. Scale bars $=5$ $\mu \mathrm{m}$ (Figs 45-48, 50); $1 \mu \mathrm{m}$ (Figs 49, 51). 

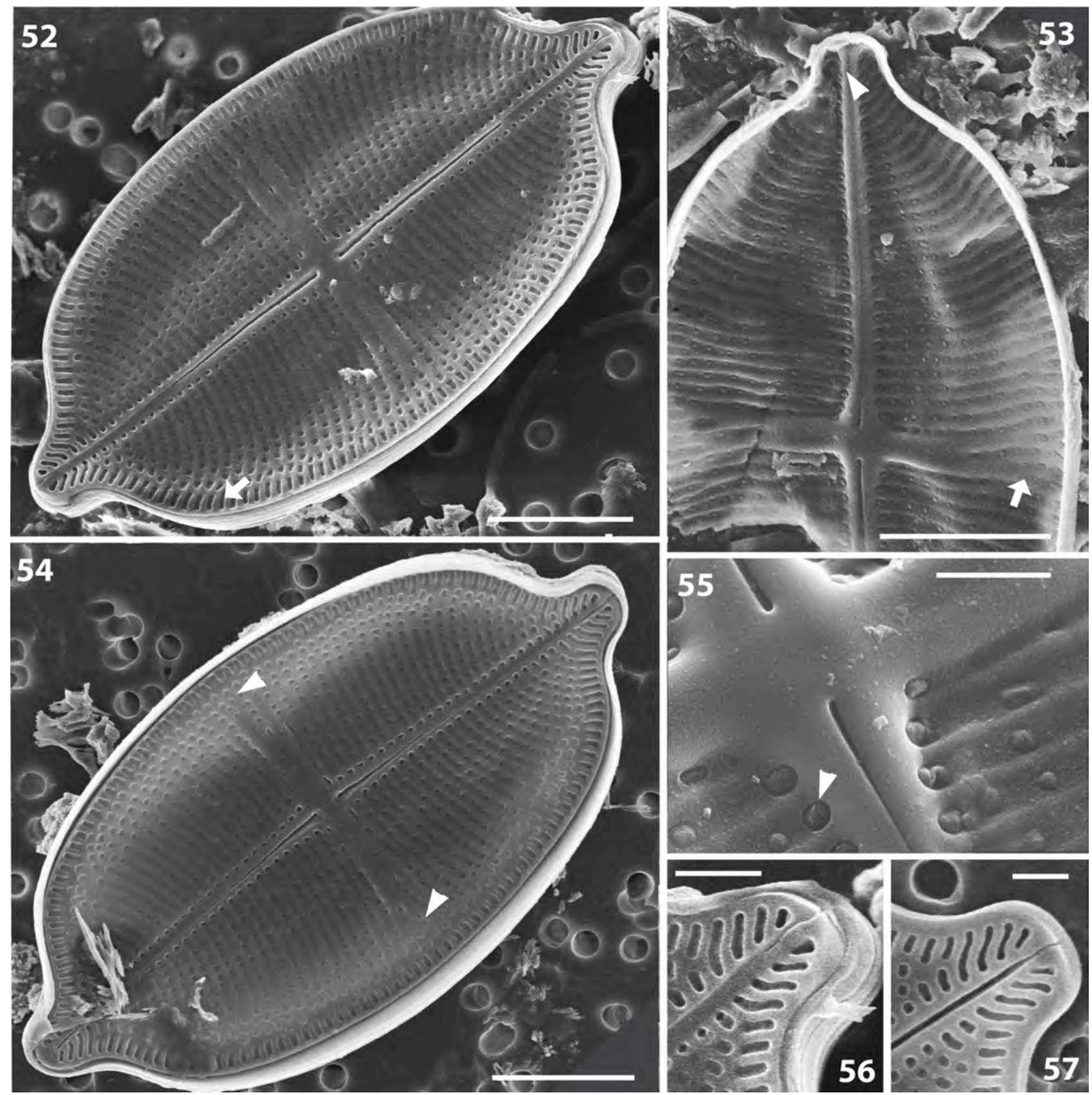

FIGURES 52-57. Achnanthes trachyderma. Individuals from Society Archipelago, SEM. 52. RV external side with laciniate stauros reaching almost the margin. 53. RV internal side with the stauros marginally delineated by very short striae (arrow), low helictoglossa (arrowhead). 54. RV external side with large stauros (arrowheads). 55. Detail of the central area in internal side, with areola domed hymenes (arrowhead). 56. RV apex with strongly bent striae with a marginal row of larger areolae. 57. Terminal raphe fissure continuing on the mantle. Scale bars = $5 \mu \mathrm{m}$ (Figs 52-54); 1 m (Figs 55-57).

Achnanthes apiculata (Greville) comb. nov. (Figs 1, 58-61, Table 2)

Basionym: Stauroneis apiculata Greville, Edinburgh New Philosophical Journal, New Series 10: 30, pl. 4, fig. 8.1859 (figure reproduced here as Fig. 1).

Description:-From David M. Williams’s photographs (Williams 1988: 47, pl. 54, figs 2, 3), it can be stated that it has an elliptic-apiculate shape, 12.5-13.0 striae in $10 \mu \mathrm{m}$, with an extended but thin stauros clearly present. Individual length 45 $\mu \mathrm{m}$. These images do not permit to determine if the taxon is a biraphid as supposed by R.K. Greville. Our type examination (Figs 58-61) shows that it is a monoraphid diatom, even if the RV striation is difficult to focus on (Figs 60, 61). The stauros extends to the half of the valve width. The SV striae, slightly radiate and present at the apices (Fig. 59, arrow), are composed of rectangular-oblong areolae, the SV sternum is narrow (Fig. 58). 
Type:-UNITED STATES. California, Patos guano (slide BM 1753, cf. Williams 1988). Figs 58-61.

Remarks:-Since Achnanthes apicultata (R.M. Patrick 1945: 167, pl. 1, figs 4-5) R.A. Matthews (1982: 193) is an invalid name, it cannot prevent the use of this name for a new combination. Stauroneis apiculata is cited by P.T. Cleve as a synonym of Achnanthes mammalis (Castracane) Cleve (1895). See the discussion in Mann (1925). Stidolph et al. (2012: pl. 22, fig. 22) illustrate an individual (with both valves and apparently uniseriate striae) as Cocconeis apiculata, with a RV stauros and no shoulders near apices, stating that 'this species will be transferred to the genus Schizostauron Grunow (1867: 28)' (A. Witkowski in litt. 2012).

Achnanthes mammalis (Castracane) Cleve (1895: 187, pl. 3, figs 13-15) (Figs 7-9, Table 2) Basionym: Rhaphoneis mammalis Castracane (1886: 48, pl. 26, fig. 3, upper valve reproduced here as Fig. 6).

Homotypic synonyms: Actinoneis mammalis (Castracane) Cleve (1895: 187), Cocconeis mammalis (Castracane) F.W.Mills (1933: 426, 435), Nematoplata mammalis (Castracane) Kuntze (1898: 146) (Fourtanier \& Kociolek 2009, 2011).

Type:-THAITI. Challenger material from the harbor of Tahiti, not found in BM.

Remarks:-Among P.T. Cleve's figures 13-15 (1895: pl. 3), the SV illustrated in figs 14, 15 (reproduced here as Figs 8 , 9) can be attributed to Raphoneis mammalis, but with a detail absent in the original description: the presence of a double row of small puncta per stria (Fig. 9). The fig. 14 (reproduced here as Fig. 7) illustrates a RV that may be identified either as Stauroneis thaitiana or as Stauroneis apiculata (Fig. 1), seeming very close to each other. Unfortunately, no Castracane slide housed in BM is labelled as Stauroneis thaitiana. Concerning Stauroneis(?) obesa Greville, the type examination by Williams (1988: 47, pl. 54, figs 5, 6) and our own observations (see below) definitively establish its belonging to the Achnanthales, with particular characters (see below).

According to Foged (1978: 28, pl. 13, fig. 6 reproduced here as Fig. 10 with permission of E. Schweizerbart), Fig. 10 would illustrate Achnanthes mammalis var. reticulata with apparently a double row of puncta per stria, and without the reticulate aspect shown in the original illustration of Achnanthes mammalis var. reticulata Cleve (1895: 187, pl. 3, fig. 16, reproduced here as Fig. 11). Furthermore, the smooth lemon shape (without shoulders) of the valve illustrated by Foged (1978) would be closer to Achnanthes mammalis var. mammalis than to Achnanthes mammalis var. reticulata.

In slide BM 2887 (R.K. Greville's collection), an individual with biseriate SV striae (Figs 62-64) and lemonshaped valves (without shoulders) may be close to Achnanthes mammalis. This taxon has a butterfly-shaped large RV stauros (Fig. 64) permitting to differentiate it from Achnanthes meisteri Hustedt in Schmidt et al. (1937: pl. 415, figs 19, 20). Note that BM 2887 is labelled as Stauroneis obesa but modern microscopy permits to resolve the unique biseriate structure of the SV striae (Figs 62, 63).

\section{Achnanthes obesa (Greville) comb. nov. (Figs 4, 65-67, Table 2)}

Basionym: Stauroneis(?) obesa Greville, Transactions of the Botanical Society of Edinburgh 8: 237, pl. 3, fig. 12.1866 (figure reproduced here as Fig. 4).

Synonym: Navicula obesa (Greville) A.Mann, pro parte typica.

Type:-AUSTRALIA. Queensland: Curteis Straits (slide BM 2736, cf. Williams 1988: 47, pl. 54, figs 5, 6).

Remarks:-From D.M. Williams's type photographs (Williams 1988): individual length $43 \mu \mathrm{m}$, SV with 13 striae in $10 \mu \mathrm{m}$, valve broad elliptic with three lateral gibbosities per hemivalve. Presence of a short stauros in fig. 5, while absent in fig. 6. The last remark implies that this taxon belongs to order Achnanthales and that the question mark by R.K. Greville probably denotes his hesitating about classifying this taxon.

Two individuals were observed in slide BM 2736 and one in BM 2593 (isotype slide also labelled as Stauroneis obesa) (Figs 65-67). The individuals have undulated lateral margins, large width, narrow SV sternum, dense and parallel SV striae (13 in $10 \mu \mathrm{m}$ ), only slightly oblique at apices, RV finely striated (ca. 21 striae in $10 \mu \mathrm{m}$, Figs 66, 67) and a high butterfly-like stauros (Fig. 67, arrowheads). In view of his unique morphology and the specific epithet, we propose Achnanthes obesa to be restricted to the individuals with broad valves and lateral gibbosities.

In slide BM 2593 we observed an individual without lateral gibbosities (length $39 \mu \mathrm{m}$, width $20 \mu \mathrm{m}, 11 \mathrm{SV}$ striae in $10 \mu \mathrm{m}, c a .23 \mathrm{RV}$ striae, not illustrated here) but its length/width is high (2.0 versus 1.7 for the individuals with gibbosities). The latter narrow individual can hardly be defined as 'obesa' and may probably pertain to Achnanthes trachyderma (see above). 

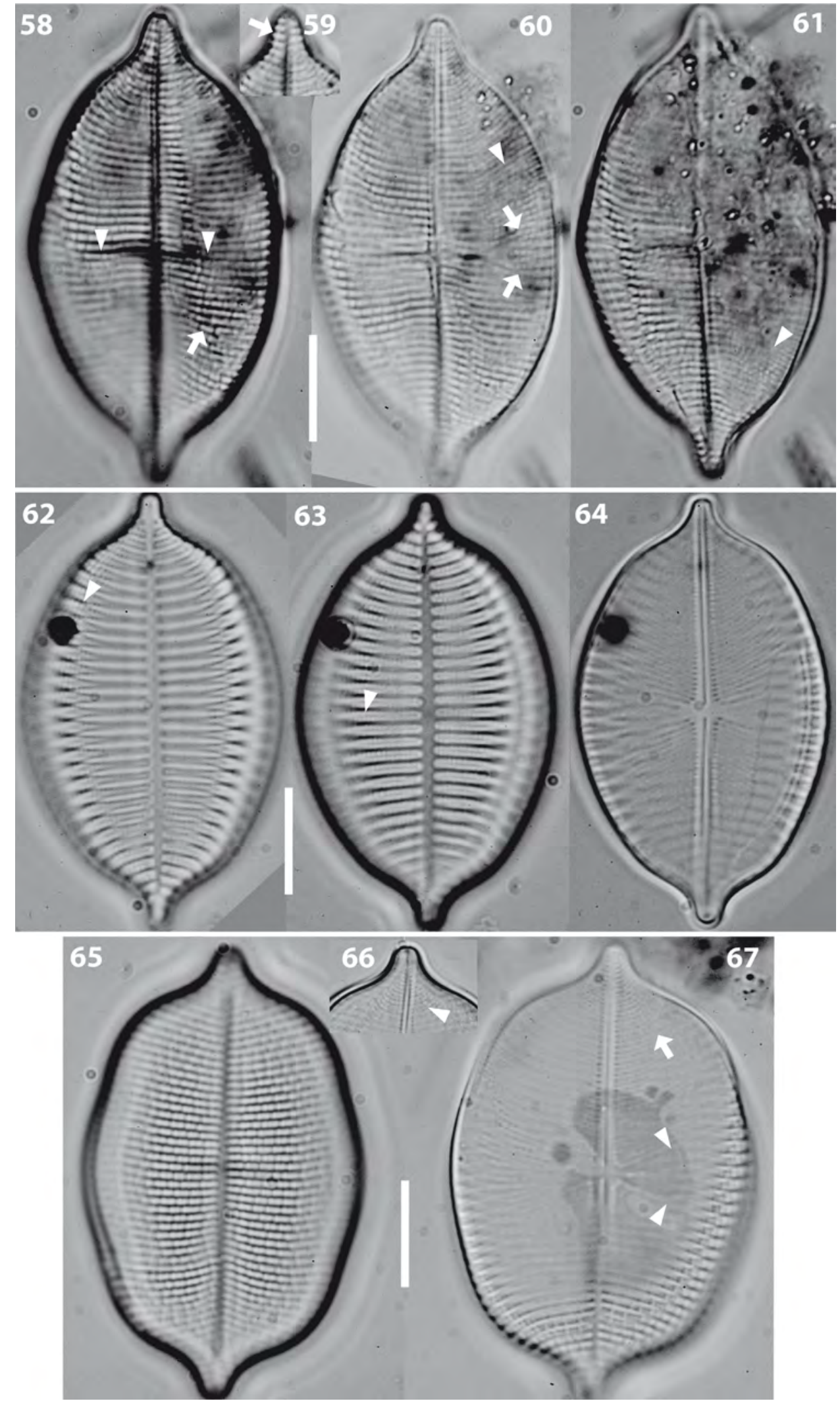

FIGURES 58-67. 58-61. Achnanthes apiculata comb. nov. 62-64. Achnanthes cf. mammalis. 65-67. Achnanthes obesa comb. nov. 58. Individual from BM 1753, note the SV oblong rectangular areolae (arrow) and the position of the underlying RV extended and narrow stauros (arrowheads). 59. Apical areolae (arrow). 60. Laciniate marginal striae around the stauros (arrows). 60, 61. RV strongly radiate striae (arrowheads). 62, 63. Individual from BM 2887 with biseriate SV striae (arrowheads). 62. Apices free of areolae. 64. RV striae strongly radiate, stauros extended and high, reaching half valve width. 65, 66. Individual from BM 2593. 67. Individual from BM 2736, note the lateral gibbosities. 65. SV rectangular areolae. 66. RV striae strongly bent on apices (arrowhead). 67. Butterfly RV stauros (arrowheads) and striae radiate and thin (arrow). Scale bars $=10 \mu \mathrm{m}$. 
Observations:-Stauroneis obesa was cited by Cleve (1895) as a synonym of Achnanthes mammalis. Mann (1925) recombined the first taxon as Navicula obesa (Greville) A.Mann, but on his illustrations (pl. 23, fig. 6 and pl. 24, fig. 1, op. cit.) the striae are strongly radiate and curved, while they are straight and only radiate at the apices in Stauroneis obesa (Williams 1988: pl. 54, figs 5, 6, reproduced here as Figs 65-67). The outline of Navicula obesa (see above) does not match the illustration by Greville (1866: pl. 3, fig. 12, reproduced in Fig. 4); however, the type of Navicula obesa remains that of its basionym, Stauroneis(?) obesa (see McNeill et al. 2012, art. 7.3) and Navicula obesa is a synonym of Achnanthes obesa. On the other hand, the biraphid diatom observed and illustrated by A. Mann under this name belongs to an indeterminate taxon of the order Naviculales.

Achnanthes schmidtii Heiden in Heiden \& Kolbe (1928: 581) (Figs 21, 22, Table 2)

Type:-pl. 198, figs 37, 38 in Schmidt et al. (1895) (designated by Simonsen 1992: 31), reproduced here as Figs 21, 22.

Remarks:-The individuals are relatively small (25-46 $\mu \mathrm{m}$ long, 13-22 $\mu \mathrm{m}$ wide, with 8.5-10.0 SV striae in $10 \mu \mathrm{m})$. Following Simonsen (1992: pl. 30, figs 6-9; fig. 7 reproduced here as Fig. 23 and fig. 6 reproduced here as Fig. 24 with permission of E. Schweizerbart), Achnanthes schmidtii is a synonym of Achnanthes citronella. Nevertheless, the RV of Achnanthes schmidtii (Fig. 24) has coarse areolae and a very reduced stauros, therefore it may be considered a separated entity.

Achnanthes citrina (A.Schmidt) Peragallo (1897: 4) (Figs 13, 14)

Basionym: Cocconeis citrina A.Schmidt in Schmidt et al. (1895: pl. 198, figs 28-30, reproduced here as Figs 13, 14).

Remarks:-The outline of this taxon is almost discoid with apiculate apices (length 39-58 $\mu$ m, width 24-49 $\mu$ m). The RV and SV have a low density of striae (ca. 8 in $10 \mu \mathrm{m}$ ); the RV striae are composed of a limited number of areolae, and there is no stauros (Fig. 14). Mann (1925: 61) evoked a certain similarity of the latter taxon with that in Schmidt's Atlas: pl. 198, figs 35, 36, 40, 'except that the lower valve [...] is very different'. A SV of this taxon has been illustrated by Desikachary (1988: vol. 5, pl. 402, fig. 7), but without a recent description or illustration of the RV, we prefer not to include this taxon in the key.

Cocconeis sabangi F.Meister (1932: 28, pl. 9, fig. 63) (Fig. 18)

Remarks:-Small taxon (23-33 $\mu \mathrm{m}$ long, 11-17 $\mu \mathrm{m}$ wide), with $12 \mathrm{SV}$ striae in $10 \mu \mathrm{m}$ and $30 \mathrm{RV}$ striae in $10 \mu \mathrm{m}$. Meister (1932) did not illustrate the RV of his new taxon, but referred to figs 33-41 in Schmidt's Atlas (pl. 198) with a remark about the incorrect striation in Schmidt's figures where the fine striation of the RV is hidden by the rough structure of the SV. Hustedt in Schmidt et al. (1937) suggests Cocconeis sabangi to be a synonym of his new combination Achnanthes citronella. Foged (1984) also indicates Cocconeis sabangi to be a synonym of Achnanthes citronella, but he also proposed Cocconeis sabangi to be a synonym of Cocconeis apiculata. This doubtful taxon is not included in the identification key.

Cocconeis apiculata A.Schmidt in Schmidt et al. (1895: pl. 198, figs 31-32) (Figs 2, 3)

Annotation in caption by A. Schmidt: 'Cocconeis apiculata A.Schmidt, following Grove = Cocconeis robusta Leud. Fortm.'

Type:-Schmidt's type material from the Cape of Good Hope has not been found, therefore Schmidt's figures 31-32 are considered as types.

Description:-Following Schmidt's figures: length 36-42 $\mu \mathrm{m}$, width 19-23 $\mu \mathrm{m}, c a$. 10-12 SV striae in $10 \mu \mathrm{m}$. No stauros. Cocconeis robusta Leuduger-Fortmorel (1879: 11, pl. 1, fig. 1 reproduced here as Fig. 5), cited by A. Schmidt as similar to his Cocconeis apiculata, shows apiculate apices that may be similar to C. apiculata, while all other features are different: in C. robusta the striae are short and robust, radiate but not curved, the axial area is wideelliptical, devoid of structures, the valve shape is elongate. Cocconeis robusta may be close to Stauroneis australis Greville (1863: 579, pl. 15, fig. 13). Stauroneis australis was typified by Williams (1988: BM 2678, holotype, pl. 54, fig. 7, individual length $110 \mu \mathrm{m}$ ). From D.M. Williams's photograph, SV has 9 striae in $10 \mu \mathrm{m}$, with striae coarser near the margin and irregularly spaced, and presents a short, well-identifiable stauros.

Remarks:-A. Schmidt in Schmidt et al. (1895) did not refer directly or indirectly to Stauroneis apiculata (Fig. 
1); therefore, this name cannot be the basionym of his Cocconeis apiculata which thus is clearly the name of a new species. In fact, the stauros present in Stauroneis apiculata (Williams 1988, pl. 54, figs 2, 3; and our Figs 1, 58, 60, 61) is not illustrated in Cocconeis apiculata A.Schmidt in Schmidt et al. (Figs 2, 3). Following these remarks, we can note that Mann (1925: 61, 62) probably improperly stated that 'Schmidt'...'makes Cocconeis apiculata (Greville) A.Schmidt and illustrates in the latter's Atlas, plate 198, figures 31, 32'. Mann (1925: 60) also proposed Schmidt Atlas's fig. 38 (unnamed in pl. 198) to be the same Cocconeis apiculata as fig. 31, with the following remark: 'it may be synonymous with Raphoneis mammalis Castracane' [here reproduced as Fig. 6] [...] and if it is the case, Castracane's name would have priority against Schmidt's one'. Finally, A. Mann concluded 'see a discussion of these forms under C. citronella, new species'. It can be noted that Mann (1925: 62) also states that 'it may be here added that Castracane's Rhaphoneis mammalis is probably a synonym of Cocconeis robustus Leuduger-Fortmorel' (see above the note about Cocconeis robusta).

Foged (1984: 28) states that 'Cocconeis apiculata and Achnanthes citronella are difficult to separate, they may belong to the same species'.

From A. Schmidt's illustrations, ascription of this species to Achnanthes rather than to Cocconeis is not possible. An examination of the original material from the Cape of Good Hope would be necessary to ascertain its taxonomical position. As it differs from most of the taxa here treated by the small rounded central area, not prolonged transversally in a stauros, we prefer not to include this doubtful taxon in the identification key.

\section{Tentative identification key based on LM observations}

1. Protracted apices, neither discontinuity nor shoulders near apices

2. SV striae uniseriate, strongly radiate, RV with a stauros, fine SV areolae, long apices with presence of SV areolae.

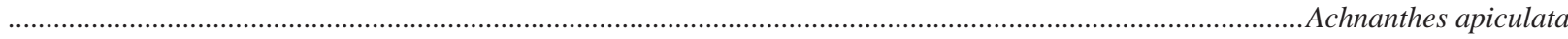

Protracted apices, shoulders, SV striae uniseriate only radiate on apices, coarse SV areolae, reticulum-like.

.Achnanthes citronella

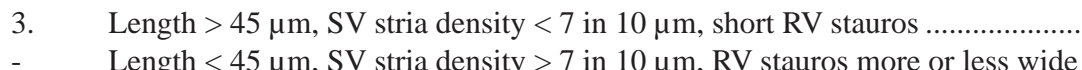

....4 .....Achnanthes obesa

4. Undulated margins, high L/W ratio......

Oblong to linear valve shape, wide RV stauros. Achnanthes trachyderma

- $\quad$ Short RV stauros, coarse RV striation

\section{Conclusion}

The taxonomic history of Achnanthes citronella seems to be intricate, unclear and sometimes confused. The lack of reliable illustrations concerning the older descriptions makes difficult the comparisons. The numerous hesitancies by A. Mann in the original description ('new name' vs. 'news species') and material labelling, the remarks by Meister (1935) about the ambiguities in the original illustration and, finally, the contradictory recent descriptions (see references in the Introduction) motivated these taxonomic notes.

Nevertheless, Achnanthes mammalis var. reticulata seems to have high similarity with Achnanthes citronella. Cocconeis sabangi, Achnanthes schmidtii and Achnanthes trachyderma comb. nov. share also some similarities among them and with the latter, but with a denser SV striation, a narrower and more linear frustule shape and a smaller length (Table 2). For these reasons, Achnanthes trachyderma has probably been often misidentified as A. citronella.

If all the bibliography available about Achnanthes citronella (Table 3) is examined, it can be noted that only Mann (1925), Meister (1935) and Wisshak et al. (2014) showed large individuals (> $45 \mu \mathrm{m}$ long): these individuals have lemon-shaped valves, with a SV sternum enlarged, a low SV stria density [6.5 in $10 \mu \mathrm{m}$ in Mann (1925) and Meister (1935), up to 10.5 in Wisshak et al. (2014)] and a relatively short RV stauros. These taxa may all refer to A. citronella (synonym: A. mammalis var. reticulata Cleve). All the other references from Table 3 refer to smaller individuals ( $<45$ $\mu \mathrm{m}$ long and often $<30 \mu \mathrm{m}$ ), with narrow-shaped valves, a dense SV striation ( $>11$ striae in $10 \mu \mathrm{m})$ and with a wide RV stauros: they may all refer to Achnanthes trachyderma comb. nov. 


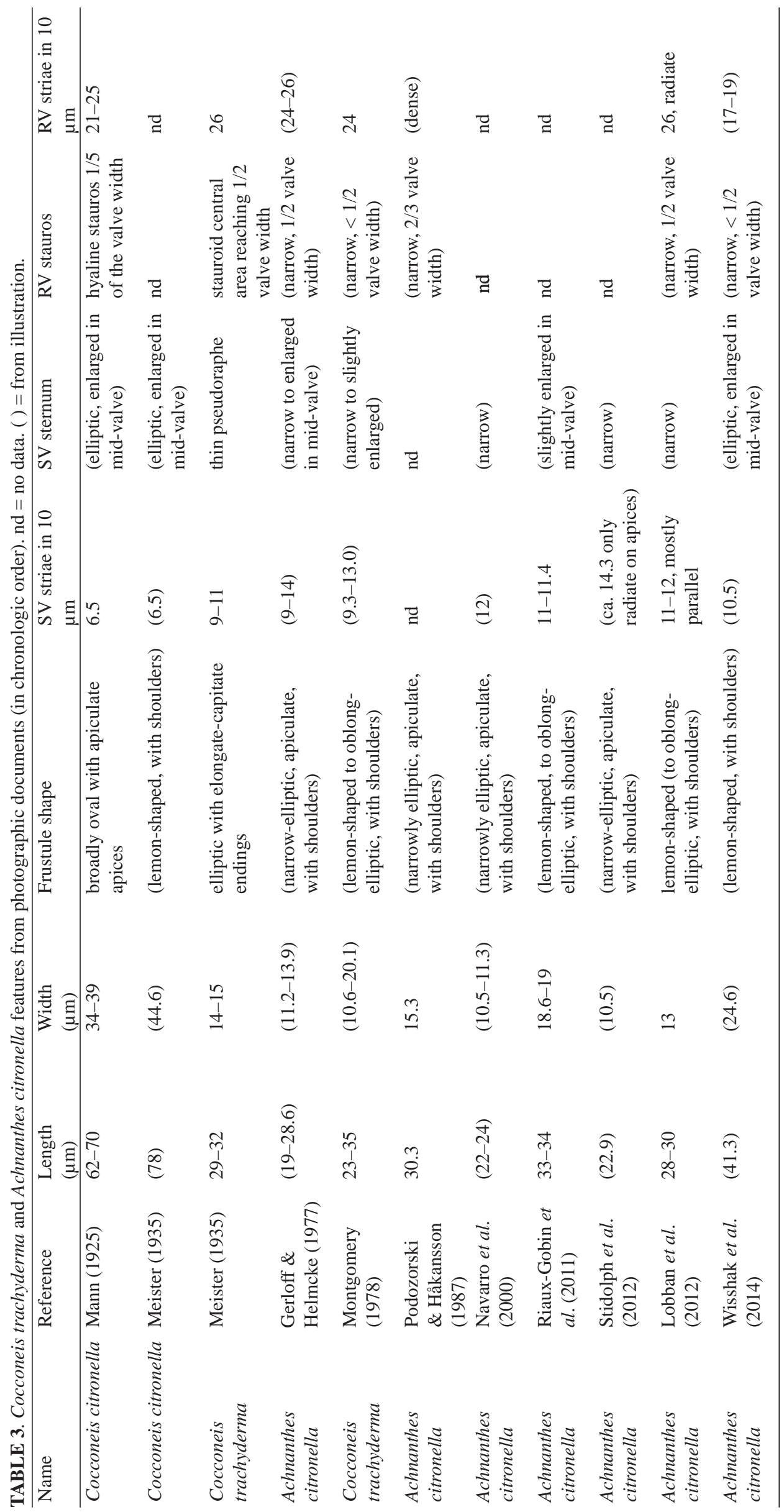


If the SV stria density seems to be a good criterion to split A. citronella from A. trachyderma comb. nov., the SV sternum shape and width may be a less strong criterion (see the large morphological variability in the individuals illustrated in Gerloff \& Helmcke 1977).

It can be noted that, except for Cocconeis apiculata (even if no LM or SEM illustrations are available), every taxon here commented shows a RV stauros (or fascia) delineated by short marginal striae: this particular stauros has a marginally laciniate aspect. Stauroneis apiculata reported (probably wrongly) by Stidolph et al. (2012) as Cocconeis apiculata, is mentioned as being soon transferred to the genus Schizostauron by A. Witkowski (A. Witkowski, in litt. 2012).

The commented taxa from the present report belong mainly to the order Achnanthales, with a marginally bifurcate or laciniate RV stauros: they may pertain to a separate group for which the correct genus name could be Schizostauron. Nevertheless, we prefer here to follow Ross (1963: 66-84) who includes the type of Schizostauron in Achnanthes.

\section{Acknowledgments}

Many thanks are due to David G. Mann and Leonie Paterson (Royal Botanic Garden Edinburgh, Edinburgh) for bibliographic help. Rusty Russel, Stan Yankowski, John Boggan, Meghann Toner and Melinda Peters from the Smithsonian Institute United States National Herbarium (Dept. of Botany, National Museum of Natural History Smithsonian Institution, Washington, DC) helped about Cocconeis citronella type slide localization and loan. We warmly thank François Straub, Lukas Taxböck and Regula Illi (M. Voigt Collection Curator, Eawag, Dübendorf, Switzerland) for their help on localization of type material from Zurich University Herbarium (Switzerland) and Dübendorf and the loan of original material. We acknowledge NHM for the loan of slides from Robert Kaye Greville's slide collection. Thanks are also due to Bank Beszteri (Alfred Wegener Institut für Polar- und Meeresforschung in der Helmholtz Gemeinschaft, Bremerhaven) and Maggy Nugues (CRIOBE-USR 3278, Laboratoire d'Excellence 'CORAIL', Perpignan) for their help in German translation. E. Schweizerbart (www.schweizerbart.de) the distributor for J. Cramer/Gebrueder Borntraeger in Stuttgart is acknowledged for giving permission to reproduce several illustrations from Bibliotheca Diatomologica 24 and Bibliotheca Phycologica 41. Two anonymous reviewers and Saúl Blanco Lanza are greatly thanked for their constructive comments. CNRS-USR 3278-Labex CORAIL funded the CORDIA projects.

\section{References}

Anonymous (1975) Proposals for a standardization of diatom terminology and diagnoses. Beihefte zur Nova Hedwigia 53: $323-354$.

Castracane, F. (1886) Report on the scientific results of the voyage of H.M.S. Challenger during the years 1873-1876. Botany 2. Her Majesty's Stationary Office, London, 178 pp.

http://dx.doi.org/10.5962/bhl.title.6513

Cleve, P.T. (1895) Synopsis of the Naviculoid Diatoms, Part II. Kongliga Svenska-Vetenskaps Akademiens Handlingar 27 (3): 1-219. http://dx.doi.org/10.5962/bhl.title.54740

Desikachary, T.V. (1988) Atlas of the Diatoms; Marine Diatoms of the Indian Ocean Region. Vol. 5. Madras Science Foundation, Madras.

Foged, N. (1975) Some littoral diatoms from the coast of Tanzania. Bibliotheca Phycologica 16: 1-127.

Foged, N. (1978) Diatoms in Eastern Australia. Bibliotheca Phycologica 41: 1-148.

Foged, N. (1984) Freshwater and littoral diatoms from Cuba. Bibliotheca Diatomologica 5: 1-243.

Fourtanier, E. \& Kociolek, J.P. (2009) Catalogue of diatom names Part 1: Introduction and bibliography. Occasional Papers of the California Academy of Sciences 156 (1): 1-168.

Fourtanier, E. \& Kociolek, J.P. (2011) Catalogue of Diatom Names. California Academy of Sciences, on-line version updated 19 Sep 2011. Available from: http://researcharchive.calacademy.org/research/diatoms/names/ (accessed 15 September 2015)

Gerloff, J. \& Helmcke, J.-G. (1977) Diatomeenschalen im elektronenmikroskopischen Bild, part 10. J. Cramer, Vaduz, pp. 1-47, pls 92-1023.

Greville, R.K. (1859) Descriptions of some new species and varieties of Naviculae, etc. observed in Californian guano. Edinburgh New Philosophical Journal, New Series 10: 25-30. 
Greville, R.K. (1863) Descriptions of new genera and species of diatoms from the South Pacific. Part II. Transactions of the Botanical Society of Edinburgh 7: 574-580. http://dx.doi.org/10.1080/03746606309467918

Greville, R.K. (1866) Descriptions of new genera and species of diatoms from the South Pacific. Part III. Transactions of the Botanical Society of Edinburgh 8: 233-238. http://dx.doi.org/10.1080/03746606609468558

Grunow, A. (1867) Diatomeen auf Sargassum von Honduras, gesammelt von Lindig. Hedwigia 6 (1-3): 1-8, 17-32, $33-37$.

Heiden, H. \& Kolbe, R.W. (1928) Die Marinen Diatomeen der Deutschen Südpolar-Expedition, 1901-1903. In: Drigalsky, E. von (Ed.) Deutsche Sudpolar-Expedition, 1901-1903, Vol. VIII, Botanik (no. 5). Walter de Gruyter \& Co., Berlin und Leipzig, pp. $447-715$.

Kisselev, I.A. (1931) Bestand und Verteilung des Phytoplanktons im Amur-Liman. Issledovaniya morei S.S.S.R. Gosusarstvennyi Gydrologicheskii Institut 14: 31-116.

Kuntze, O. (1898) Revisio Generum Plantarum. Part III. Leipzig, pp. 1-576.

Leuduger-Fortmorel, G. (1879) Catalogue des diatomées de l'île Ceylan. Mémoires de la Société d’Emulation des Côtes-du-Nord, St. Brieuc, 73 pp.

Lobban, C.S., Schefter, M., Jordan, R.W., Arai, Y., Sasaki, A., Theriot, E.C., Ashworth, M., Ruck, E.C. \& Pennesi, C. (2012) Coral-reef diatoms (Bacillariophyta) from Guam: new records and preliminary checklist, with emphasis on epiphytic species from farmer-fish territories. Micronesica 43: 237-479.

Mann, A. (1925) Marine diatoms of the Philippines Islands. United States National Museum Bulletin 100 (6): 1-182.

Matthews, R.A. (1982) Biological surveys on the Savannah River in the vicinity of the Savannah River Plant (1951-1976). DP-1531. E.I. du Pont de Nemours \& Co, Savannah River Laboratory, Aiken, S.C., 230 pp.

McNeill, J., Barrie, F.R., Buck, W.R., Demoulin, V., Greuter, W., Hawksworth, D.L., Herendeen, P.S., Knapp, S., Marhold, K., Prado, J., Prud'homme van Reine, W.F., Smith, G.F., Wiersma, J.H. \& Turland, N.J. (2012) International Code of Nomenclature for algae, fungi and plants. Regnum Vegetabile 154: 1-208.

Meister, F. (1932) Kieselalgen aus Asien. Verlag von Gebrüder Borntraeger, Berlin, 56 pp, 19 pls.

Meister, F. (1935) Seltene und neue Kieselalgen. Berichte der Schweizerischen Botanischen Gesellschaft 44: 87-108.

Mills, F.W. (1933) An index to the genera and species of the diatomaceae and their synonyms. Part 6 (Ch-Co). Wheldon \& Wesley, Limited, London, pp. 373-448.

Montgomery, R.T. (1978) Environmental and ecological studies of the diatom communities associated with the coral reefs of the Florida Keys. A taxonomic study of Florida Keys: Benthic diatoms based on SEM. Unpublished Ph.D. thesis, Florida State University, College of Arts and Sciences, Tallahassee, Florida USA, 336 pp.

Navarro, J.-N., Micheli, C.J. \& Navarro, A.-O. (2000) Benthic diatoms of Mona Island (Isla de Mona), Puerto Rico. Acta Cientifica 14: $103-143$.

Patrick, R.M. (1945) A taxonomic and ecological study of some diatoms from the Pocono Plateau and adjacent regions. Farlowia 2 (2): 143-221.

Peragallo, M. (1897) Le Catalogue Général des Diatomées. Clermont-Ferrand. 1: i-xviii, p. 1-472. [issued in fascicles at various dates] Podzorski, A.C. \& Håkansson, H. (1987) Freshwater and marine diatoms from Palawan. Bibliotheca Diatomologica 13: 1-244.

Riaux-Gobin, C., Romero, O., Compère, P. \& Al-Handal, A.Y. (2011) Small-sized Achnanthales (Bacillariophyta) from coral sands off Mascarenes (Western Indian Ocean). Bibliotheca Diatomologica 57: 1-234.

Riaux-Gobin, C., Romero, O.E., Coste, M. \& Galzin, R. (2013) A new Cocconeis (Bacillariophyceae) from Moorea Island, Society Archipelago, South Pacific Ocean with distinctive valvocopula morphology and linking system. Botanica Marina 56 (4): 339-356. http://dx.doi.org/10.1515/bot-2012-0162

Riaux-Gobin, C., Compère, P., Coste, M., Straub, F. \& Taxböck, L. (2014) Cocconeis napukensis sp. nov. (Bacillariophyceae) from Napuka Atoll (South Pacific) and lectotypification of Cocconeis subtilissima Meister. Fottea 14: 209-224. http://dx.doi.org/10.5507/fot.2014.016

Ross, R. (1963) The diatom genus Capartogramma and the identity of Schizostauron. Bulletin of the British Museum (Natural History), Botany 3 (2): 47-92.

Ross, R., Cox, E.J., Karayeva, N.I., Mann, D.G., Paddock, T.B.B., Simonsen, R. \& Sims, P.A. (1979) An amended terminology for the siliceous components of the diatom cell. Nova Hedwigia, Beiheft 64: 513-533.

Round, F.E., Crawford, R.M. \& Mann, D.G. (1990) The diatoms: biology and morphology of the genera. Cambridge University Press, Cambridge, 747 pp.

Schmidt, A., Schmidt, M., Fricke, F., Heiden, H., Müller, O. \& Hustedt, F. (1874-1959) Atlas der Diatomaceen-kunde. Aschersleben, Leipzig, Heft 1-120, Tafeln 1-480.

Schmidt, A., Schmidt, M., Fricke, F., Heiden, H., Müller, O. \& Hustedt, F. (1895) Atlas der Diatomaceen-kunde. Aschersleben, Leipzig, Series V, Heft 50, Tafeln 197-200. 
Schmidt, A., Schmidt, M., Fricke, F., Heiden, H., Müller, O. \& Hustedt, F. (1937) Atlas der Diatomaceen-kunde. Aschersleben, Leipzig, Series VIII, Heft 104, Tafeln 413-416. [F. Hustedt]

Simonsen, R. (1992) The diatom types of Heinrich Heiden in Heiden \& Kolbe 1928. Bibliotheca Diatomologica 24: 1-100.

Stidolph, S.R., Sterrenburg, F.A.S., Smith, K.E.L. \& Kraberg, A. (2012) Stuart R. Stidolph Diatom Atlas. U.S. Geological Survey OpenFile Report 2012-1163. Available from: http://pubs.usgs.gov/of/2012/1163/ (accessed 15 September 2015)

VanLandingham, S.L. (1969) Catalogue of the fossil and recent genera and species of diatoms and their synonyms. Part III. Coscinophaena through Fibula. Verlag von J. Cramer, Lehre, pp. 1087-1756.

Williams, D.M. (1988) An illustrated catalogue of the type specimens in the Greville diatom herbarium. Bulletin of the British Museum (Natural History) Botany Series 18 (1): 1-148.

Wisshak, M., Alexandrakis, E. \& Hoppenrath, M. (2014) The diatom attachment scar Ophthalmichnus lyolithon igen. et isp. n. Ichnos 21: 111-118.

http://dx.doi.org/10.1080/10420940.2014.907572 